\section{Response to: 'Protective effects of antimalarials in Chinese patients with systemic lupus erythematosus' by Wang et al}

In their letter, Wang et $a l^{1}$ present further data showing impressively the beneficial effects of antimalarials and in particular hydroxychloroquine (HCQ) in patients with systemic lupus erythematosus. They refer to our article on the interference of HCQ with proinflammatory signalling pathways. ${ }^{2}$ We showed that HCQ prevents activation of endosomal NADPH-oxidase (NOX) by cell surface receptors, for example, the receptors

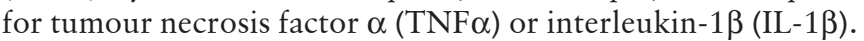
Since signalling of both receptors is mediated in large part but not exclusively by endosomal NOX, HCQ can be regarded as an inhibitor of TNF $\alpha$ and IL-1 $\beta$. While we would like to agree with Wang et al that this pharmacological effect of HCQ may be an explanation of its therapeutic efficacy, their data do not provide any clue to the potential mechanisms of the observed effects. Numerous other potentially beneficial properties of HCQ have been described in the past. ${ }^{3}$ Recently, Schreiber $e t$ al reported in a small cohort of patients with the antiphospholipid syndrome that treatment with HCQ for 3 months significantly reduced the amount of soluble tissue factor (TF) in plasma. ${ }^{4}$ Since TF can be induced by antiphospholipid antibodies directly by activation of endosomal $\mathrm{NOX}^{5}$ or indirectly via $\mathrm{TNF} \alpha$, this provides some indirect evidence that inhibition of endosomal NOX may be relevant in vivo in humans. Interestingly, beneficial metabolic effects of HCQ have been described including lowering of low-density lipoprotein cholesterol and improving insulin resistance. ${ }^{6}$ The latter effect would be compatible with an anti-TNF $\alpha$ effect of HCQ. In summary, having identified many pharmacological effects of HCQ, we now need to understand which of them is responsible for the improved patient outcome. This will require clinical studies focused on the different known targets of HCQ.

\section{Nadine Müller-Calleja, Karl J Lackner}

Institute of Clinical Chemistry and Laboratory Medicine, University Medical Center Mainz, Mainz, Germany
Correspondence to Dr Nadine Müller-Calleja, Institute of Clinical Chemistry and Laboratory Medicine, University Medical Center Mainz, Mainz D-55131, Germany; nadine.mueller-calleja@unimedizin-mainz.de

Handling editor Josef S Smolen

Competing interests None declared.

Patient consent Not required.

Provenance and peer review Commissioned; internally peer reviewed.

(c) Author(s) (or their employer(s)) 2019. No commercial re-use. See rights and permissions. Published by BMJ.

\section{Check for updates}

To cite Müller-Calleja N, Lackner KJ. Ann Rheum Dis 2019;78:e81.

Received 4 June 2018

Accepted 8 June 2018

Published Online First 26 June 2018

\section{CSinked}

- http://dx.doi.org/10.1136/annrheumdis-2018-213819

Ann Rheum Dis 2019;78:e81. doi:10.1136/annrheumdis-2018-213853

\section{REFERENCES}

1 Wang F, Zhang W, Wang S, et al. Protective effects of antimalarials in Chinese patients with systemic lupus erythematosus. Ann Rheum Dis 2018;xy:zzz.

2 Müller-Calleja N, Manukyan D, Canisius A, et al. Hydroxychloroquine inhibits proinflammatory signalling pathways by targeting endosomal NADPH oxidase. Ann Rheum Dis 2017;76:891-7.

3 Rainsford KD, Parke AL, Clifford-Rashotte M, et al. Therapy and pharmacological properties of hydroxychloroquine and chloroquine in treatment of systemic lupus erythematosus, rheumatoid arthritis and related diseases. Inflammopharmacology 2015;23:231-69.

4 Schreiber K, Breen K, Parmar K, et al. The effect of hydroxychloroquine on haemostasis, complement, inflammation and angiogenesis in patients with antiphospholipid antibodies. Rheumatology 2018;57:120-4.

5 Prinz N, Clemens N, Canisius A, et al. Endosomal NADPH-oxidase is critical for induction of the tissue factor gene in monocytes and endothelial cells. Lessons from the antiphospholipid syndrome. Thromb Haemost 2013;109:525-31.

6 Rempenault C, Combe B, Barnetche T, et al. Metabolic and cardiovascular benefits of hydroxychloroquine in patients with rheumatoid arthritis: a systematic review and meta-analysis. Ann Rheum Dis 2018;77:98-103. 